\title{
Existence of Cultural Rights of Society Law in The Determination of Land Boundaries in Onan Runggu Village Communities, Kecamatan, Toba Samosir District
}

\author{
Amri Panahatan Sihotang ${ }^{1}$, Sukimin ${ }^{2}$ \\ \{amripanahatan20@gmail.com ${ }^{1}$, sukimin.@usm.ac.id ${ }^{2}$ \}
}

Faculty of Law, Semarang University, Semarang, Indonesia ${ }^{1}$, Faculty of Law, Semarang University, Semarang, Indonesia ${ }^{2}$

\begin{abstract}
This study aims to determine the existence of the customary rights of customary law communities in the customary law community in Onanrunggu Village, Onanrunggu District, Toba Samosir Regency in determining the boundaries of customary land and the obstacles faced by customary law communities in determining the boundaries and utilization of ulayat land. This type of research is sociological juridical. Field research to obtain primary data was carried out by examining the research location in Onanrunggu Village, Onanrunggu District, Samosir Regency. Data were analyzed using descriptive analytical methods to answer the problem. The state, in this case the local government, pays less attention to and involves leaders of the Customary Law Community, Customary Elders and people who are considered to be the forerunners of the formation of Onanrunggu Village in determining the boundaries of Customary Land, Customary Heritage Land, both clan and private groups.
\end{abstract}

Keywords: Existence; Rights; Ulayat; Society; Adat

\section{Introduction}

Constitutional guarantees for the existence of Customary Law Communities are contained in Article 18B paragraph (2) of the 1945 Constitution of the Republic of Indonesia which reads "The state recognizes and respects indigenous peoples and their traditional rights as long as they are alive and in accordance with developments. society and the principles of the Unitary State of the Republic of Indonesia, which are regulated in law".

Traditional rights or customary rights are one of the rights that become a priority scale in legal protection for Indigenous Peoples in Indonesia in the agrarian sector. This can be seen in Article 3 of Law Number 5 Year 1960 concerning Basic Agrarian Principles which reads "By considering the provisions in Articles 1 and 2 the implementation of customary rights and similar rights of customary law communities, insofar as it still exists, it must be in such a way that it in the national and state interests, which are based on national unity and must not conflict with laws and other higher regulations ".

The regulation of customary rights in the constitution and statutory regulations is a guarantee provided by the state for Indigenous and Tribal Peoples who still uphold the values of recognition in terms of land rights, especially in terms of land ownership rights which are in the form without certificates.

The Basic Agrarian Law Number 5 of 1960 concerning Basic Regulations for Basic Agrarian Law (UUPA), has contained a provision which states that this law is based on customary law (Article 5), and recognizes one of the most important aspects of indigenous peoples' rights related to with his living space as stated in Article 3, namely what is known as ulayat rights. Article 3: "Taking into account the provisions in Article 1 and Article 2 the implementation of customary rights and similar rights from the customary law community, as long as they still exist, it must be in such a way that it is in accordance with the national and state interests based on national unity 
and may not be permitted. contrary to laws and higher regulations". With this provision, it is clear that ulayat rights are recognized, but with certain limitations regarding their existence, that is, if in fact they still exist, and their implementation must meet limitative requirements.

In the hope of democracy in Indonesia today, some people in the regions are demanding regional rights, one of which is the recognition of the rights of indigenous peoples, namely customary land. It's just that the State is not yet clear about including customary land as clear and definite rights and what its implementation looks like. Concerns that the status of communal land rights being granted can be a problem for the State, because of even greater interests. Many of these land problems occur in several areas that are diluted because of these interests, the dominance of the State in controlling land by the State, causing the State to be trapped in land conflicts, both vertical and horizontal conflicts. The clarity that is still considered vague in our constitution, namely the 1945 Constitution regarding the form of recognition of the rights of indigenous peoples, in terms of customary land. The UUPA does not include customary land as a status of rights owned by indigenous communities, but rather emphasizes control of land by the State. Meanwhile, ownership is carried out individually. This condition is inseparable from the customary law community in the Batak community of Onanrunggu Village where the local government does not pay attention to the customary rights of the customary law community contained in the community. As a result of this, internal conflicts from the community, especially those caused by the problem of land boundaries, resulted. Land that is owned for generations (inherited land) is a source of conflict. Looking at the background of the problems above, the writer makes a problem. What is the existence of the customary rights of the customary law community in determining land boundaries in the community of Onanrunggu Village, Onanrunggu District, Toba Samosir Regency?

\section{Literature Review}

According to Abidin Zaenal existence is a dynamic process, a being or being. This corresponds to the origin of the word existence itself, namely exsistere, which means going out of, beyond or overcoming. So existence is not rigid and stagnant, but flexible or springy and experiences development or regresses, depending on the ability to actualize its potentials. "According to Nadia Juli Indrani, we can also recognize existence with one word, namely existence. Where the existence in question is the influence of our presence or absence [1].

G. Kertasapoetra and friends emphasize the term ulayat rights in their book Land Law, UUPA Guarantee for the Success of Land Utilization, stating that; Ulayat rights are rights owned by a legal association (village, ethnic group), where the members of the community (legal association) have the right to control the land, the implementation of which is regulated by the head of the association (the head of the tribe / head of the village concerned)" [2].

\section{Research Methods}

Based on the formulation of the problem, this type of writing is juridical empirical / sociological. Sociological juridical is something that highlights problems based on legal aspects that actually occur in the field or in the community. In this case, the existence of the customary rights of the customary law community in determining land boundaries in the community of Onanrunggu Village, Onanrunggu District, Toba Samosir Regency. The specification of this research is descriptive analytical because this research will describe the existence of customary law communities and analyzed based on applicable laws and regulations [3].

\section{Results And Discussion}


The existence of customary rights of customary law communities in determining land boundaries in the community of Onanrunggu Village, Onanrunggu District, Toba Samosir Regency.

Ulayat rights are not individual property rights, but have a private dimension and have tenure rights guaranteed by Law No.5 of 1960 on the Basic Agrarian Law, article 3 because customary law is the main basis, but not all of them are that customary law is the basis main but also complementary, namely the characteristics stipulated in article 5, article 56 and article 58 of the Basic Agrarian Law. The customary rights are a series of powers and obligations of customary law communities, which relate to land located within their territory, which is the main support for the livelihoods and lives of the people concerned throughout the ages, namely those related to the collective rights to own the land, including public law, in the form of duties. and the authority to manage, regulate and lead the allocation and control and maintenance.

The provisions in Article 3 of the Basic Agaria Law stem from the recognition of customary rights in the national land law, which is accompanied by 2 conditions, namely regarding its existence and implementation. If in reality the particular customary law community group concerned still exists, the implementation must be in such a way that it is in accordance with the national and state interests, which are based on national unity and may not conflict with laws and other higher regulations, this is explained in article 3 and General Explanation number II number 3 of the Basic Agrarian Law.

The recognition of customary rights is fundamentally derived from article 18 paragraph 2 of the 2nd amendment of the 1945 Constitution, article 3 of the Basic Agrarian Law and General Explanation number II number 3 of the Basic Agrarian Law, and is defined in article 1 points 1 and 2. Agrarian Regulation / Head of the National Land Agency No.5 of 1999, Presidential Decree No.34 of 2003, Presidential Decree No. 36 of 2005 concerning legal certainty.

The contents of the customary rights authority are:

1. Regulating and administering land use and maintenance;

2. Regulating the legal relationship between people and land; and

3. Regulate and determine legal relationships between people and legal actions relating to land, such as buying and selling, inheritance and others.

Recognition of the existence of customary law and respect for it in the form of adopting or accepting the legal values of customary land into national agrarian law is shown in article 3 of the Basic Agrarian Law, which contains political material on land law, that customary rights represent rights to land within the framework of land law. custom can be enforced if;

1. Customary rights or similar still exist in the life order of customary law communities;

2. Is in line with the principles of the Unitary State of the Republic of Indonesia so that enforcement is in accordance with the national interest and the interests of the state;

3. Not contradicting with higher laws and regulations, meaning that the legal position of customary land is under the Basic Agrarian Law and national land law.

The recognition of the existence of customary rights of customary law communities is qualified by Boedi Harsono, if; First, there is still a group of people as members of a certain customary law association, which is a customary law community. Second, there is still an area that is the ulayat of the customary law community, which is recognized as land belonging to its citizens and Third, there is still a customary ruler who in fact and is recognized by the members of the customary law community concerned, carries out daily activities as the implementer of rights. Ulayat [4].

The existence of the customary rights of the customary law community in determining land boundaries in the community in Onanrunggu Village:

1) The customary rights of the Customary Law Community in Onanrunggu Village have not been fully handed over to the traditional elders because there is still arrogance from the local government

2) In determining the boundaries of Customary land which should have included witnesses from Indigenous Community leaders, traditional elders, parents who were the forerunners of the formation of the Village were not included by local government officials. 
3) Customary law which has become the norm or rule that lives in the Onanrunggu Village community has undergone changes with the unstoppable influx of modernization and globalization.

4) Government officials in the village of Onanrunggu very much dominate in determining the boundaries of customary lands.

\section{Conclusion}

a. Hak Ulayat is a collective right to land ownership that needs to be taken into account optimally by government officials, including public law, which has the authority to manage, regulate, lead the allocation and control and maintenance.

b. The customary land rights of the Customary Law Community in Onanrunggu Village in determining the boundaries of both customary land, customary inheritance land and private inheritance land do not involve traditional community leaders, customary elders and the people who were the forerunners of the formation of the village.

\section{References}

[1] V. Diijk, Pengantar Hukum Adat Indonesia. Bandung: Sumur, 1983.

[2] G. Kertasapoetra, R. . Kartasapoetra, A. Kartasapoetra, and A. Setiady, Hukum Tanah, Jaminan Undang-Undang Pokok Agraris Bagi Keberhasilan Pendayagunaan. Jakarta: Bina Aksara, 1985.

[3] Mardalis, Metode Penelitian Suatu Pendekatan Proposal. Jakarta: Raja Grafinso Persada, 2001.

[4] B. Harsono, Hukum Agraria Indonesia: Sejarah Pembentukan UUPA, Isi dan Pelaksanaannya. Jakarta: Djambatan, 2005. 